\title{
What are the Potential Benefits of Using Proton Therapy in Taiwanese Cancer Patients?
}

\author{
Wei-Heng $\mathrm{Kao}^{1}$, Yi-Liang Shen ${ }^{1}$, Ji-Hong Hong ${ }^{1,2,3}$
}

\begin{abstract}
The potential benefits of proton therapy have been established in pediatric cancer, skull base tumor, uveal melanoma, and other types of cancers. Western and Asian countries, however, have differences in the pattern of cancer incidence; this leads to the difference in patient demographics for proton therapy. Furthermore, the advancement of the scanning beam technique in proton therapy greatly expands the capability of proton therapy in disease sites with great complexity. In this review, we focus on the cancers with high incidence in Taiwan, based on the Cancer Registry Annual Report, 2011, Taiwan. The potential case number and clinical benefits from proton therapy are evaluated and discussed. Two endemic cancers, hepatocellular carcinoma and head and neck cancer, are considered to be the major disease types appropriate for proton therapy in Taiwan. Primary lung cancer and left side breast cancer, which are popular in western countries as well as in Taiwan,

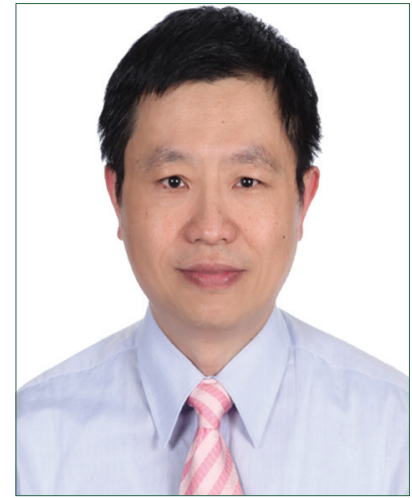

Dr. Ji-Hong Hong are included for discussion. The issue of cost-effectiveness for proton therapy is also reviewed. Finally, we point out the clinical trials that should be conducted for proton therapy in Taiwan. (Biomed J 2015;38:391-398)
\end{abstract}

\section{Key words: head and neck cancer, hepatocellular carcinoma, proton therapy, Taiwanese cancer patients}

\section{Brief history of proton therapy}

I n 1946, Dr. Robert Wilson proposed to use protons in treating cancer. ${ }^{[1]}$ The first proton treatment was administered by Berkeley Radiation Laboratory in 1954. Although several research institutes around the world have conducted proton treatment for tumors with limited depth, the first hospital-based proton center, which has a high energy proton beam to treat a variety of tumors, was established in Loma Linda University at California in 1990 . By the end of 2013, more than 25 proton centers in the world had multiple treatment rooms and high energy proton beams to treat deeply seated tumors; more than 100,000 patients were treated by proton beams. The number of proton treatment facilities is expected to rapidly increase due to the introduction of the single-room design. Chang Gung Memorial Hospital-Linkou set up the first proton center in Taiwan and started patient treatment in September 2014.

\section{The physical characteristics and potential clinical benefits of proton beams}

$\mathrm{X}$-ray (photons) emitted by a linear accelerator is the most common treatment beam for current radiotherapy. Compared to the proton beam, the X-ray has the disadvantages of a higher entrance dose in front of the tumor and a remarkable residual dose after the tumor, whereas protons pass through tissues with a lower entrance dose, but release large amounts of energy when they reach the desired depth of treatment (the Bragg peak) and deposit no dose to the normal tissues behind the tumor [Figure 1]. Due to this physical characteristic, the proton beam protects normal tissues after the treatment target from radiation damage.

From the ${ }^{1}$ Department of Radiation Oncology, Chang Gung Memorial Hospital at Linkou, Chang Gung University College of Medicine, Taoyuan, Taiwan; ${ }^{2}$ Institute for Radiological Research, Chang Gung University/Chang Gung Memorial Hospital, Taoyuan, Taiwan; ${ }^{3}$ Department of Medical Imaging and Radiological Science, College of Medicine, Chang Gung University, Taoyuan, Taiwan Received: Aug. 06, 2014; Accepted: Jan. 26, 2015

Correspondence to: Dr. Ji-Hong Hong, Department of Radiation Oncology, Chang Gung Memorial Hospital at Linkou. 5, Fusing St, Gueishan, Taoyuan 333, Taiwan (ROC). Tel.: 886-3-3281200 ext. 7000; Fax: 886-3-3280797; E-mail: jihong@ adm.cgmh.org.tw

DOI: $10.4103 / 2319-4170.153211$ 
Since a single Bragg peak is not wide enough to cover a whole tumor, a summation of multiple peaks [Spread-out Bragg Peak (SOBP)] is needed to broaden the coverage to the size of the tumor. The formation of SOBP increases the entrance dose but still maintains a minimal exit dose [Figure 1].

The potential benefits of proton beam in terms of dose distribution are demonstrated in Figure 2. Figure 2A presents the dose comparisons between proton beam and the most advanced X-ray technique, volumetric modulated arc radiotherapy (VMAT), to a hepatocellular carcinoma (HCC). The low dose bath to normal liver and gastrointestinal tissue in the VMAT is spared in the proton beam. This low dose bath is a determining factor for radiation-induced liver toxicity because normal liver tissues have a poor tolerance to radiation damage. The tolerance is even worse for livers with cirrhosis or viral infection commonly seen in HCC patients at Taiwan. The difference in the low dose bath becomes bigger with the increasing tumor size. Figure 2B shows the dose distribution of intensity-modulated proton therapy (IMPT) versus VMAT in nasopharyngeal carcinoma (NPC). In VMAT, there are substantial doses to the buccal mucosa, tongue, and submandibular and submental regions, which are not considered as treatment targets for NPC. These regions could be effectively spared by IMPT. These advantages in the dose distribution have high possibility to translate into clinical benefits to patients.

\section{Evolution of the proton treatment technique}

The conventional proton treatment was mainly given by passive scattering, a technique relatively insensitive to organ motion caused by respiration. Through this technique, sufficient clinical evidence was obtained to show the advantages of proton over X-ray in pediatric CNS tumor,

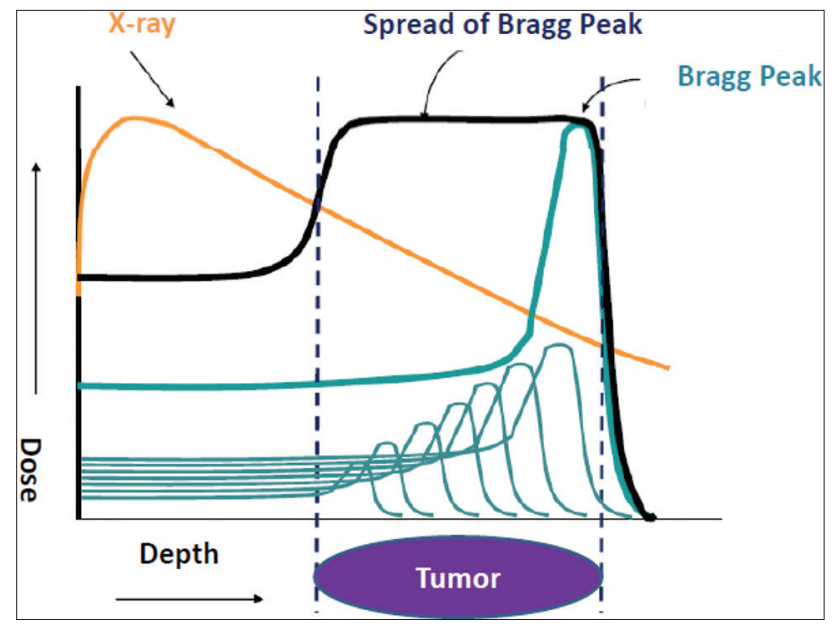

Figure 1: Comparisons of the physical characteristics between proton beam and X-ray. skull base sarcoma, ocular melanoma, liver tumor, and some other tumors. ${ }^{[2-5]}$ However, this technique has several limitations such as a limited field size, unconformity to the tumor shape in the entrance region, using complex combinations in treating tumors with irregular shapes, requirements of a collimator and a compensator, and slow throughput by multiple field treatment. Due to these limitations and prevalent cancer types, more than $60 \%$ of cases in the US proton centers were prostate cancer patients; this application raises a lot of arguments. ${ }^{[6,7]}$ In 1996, the scanning technique was first employed in proton therapy by the Paul Scherrer Institute (PSI) in Switzerland, but it was not used in other centers before 2009. The development of advanced scanning technique is another milestone for proton therapy, because it has the capability to cover a large field, conduct IMPT, and treat tumors with complex geometry. The best examples for this application are head and neck cancers, in which treatment often needs large fields to cover the primary tumor and neck lymphatics, and tumors which have target shape with complexity and are close to organs at risk.

In 2011, out of 92,682 new patients with invasive cancer in Taiwan, around 35-40\% received radiotherapy as part of their cancer treatment, while this figure is up to $60 \%$ in the United States. Since proton therapy is an emerging tool for radiotherapy, we should learn its potential benefits for specific cancer types in Taiwan. However, this issue has never been addressed in literature despite our extensive research, and will be discussed in the following sections.

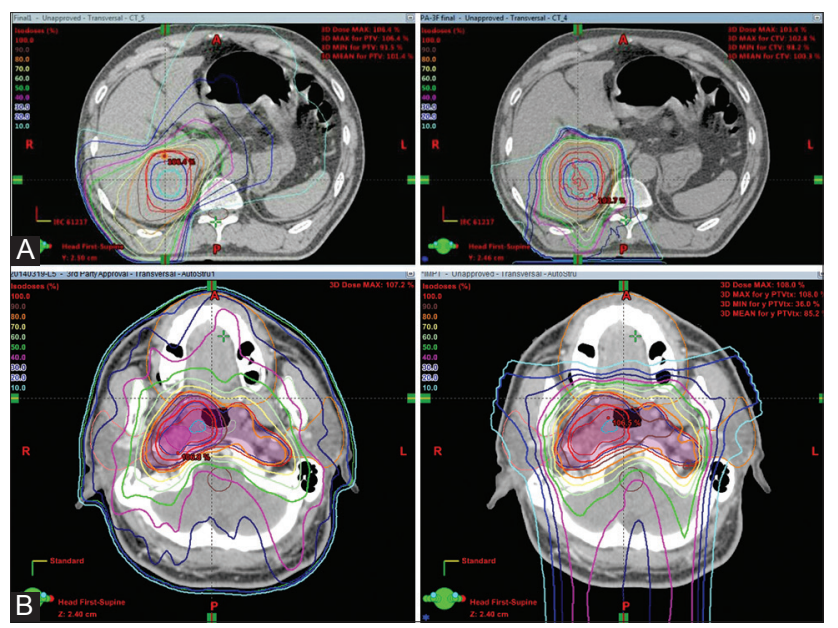

Figure 2: Comparisons of dose distribution of X-ray and proton therapy in HCC and head and neck tumor. (A) The passive scattering technique of proton treatment (right) and the volumetric arc radiotherapy (VMAT) of X-ray treatment (left) administered to treat hepatocellular carcinoma. (B) The intensity-modulated proton treatment (IMPT, right) by scanning beam technique and the VMAT of X-ray (left) administered to treat nasopharyngeal carcinoma. 


\section{Potential clinical benefits of proton therapy on cancers with high prevalence in Taiwan but not in western countries}

\section{Primary liver tumor}

Taiwan is an endemic region for $\mathrm{HCC}$ due to the high prevalence of the carrier status of hepatitis B and/or C infection. In 2011, more than 10,000 patients with primary liver tumor were diagnosed. ${ }^{[8]}$ Surgery, percutaneous ethanol injection therapy (PEIT), radiofrequency ablation (RFA), and transcatheter arterial chemoembolization (TACE) are the major treatments for $25 \%, 11 \%$, and $27 \%$ HCC patients, respectively, in Taiwan. Although RFA is the preferred local treatment for non-surgical patients, incomplete ablation and local relapse rate are associated with increasing tumor size ${ }^{[9]}$ therefore, RFA is not recommended for tumors larger than $5 \mathrm{~cm} \cdot{ }^{[10]}$ Meanwhile, around $80 \%$ patients will have intrahepatic relapse within 5 years of surgery or RFA.

Several proton centers in Japan have demonstrated the efficacy of proton therapy on the local tumor control of HCC. A Phase II trial using proton therapy for patients not suitable for surgery or local treatment showed a $96 \%$ local progression-free survival rate at 2 years. ${ }^{[1]]}$ The local control from other Japanese series ranged from 81 to $95 \% .^{[12-14]}$ The respective local tumor control rates were $96 \%, 84 \%$, and $43 \%$ for tumor size smaller than $5 \mathrm{~cm}, 5-10 \mathrm{~cm}$, and larger than $10 \mathrm{~cm},{ }^{[12]}$ and minimal complication rates were reported from these series. The local tumor control rate was comparable and similar between proton beam and carbon ion. ${ }^{[13]}$ For patients whose tumor had portal vein thrombosis, surgery or local treatment was often difficult to administer, and Sorafenib had only a limited effect on progression-free survival; proton therapy was shown to improve the progression of local tumor and patients' survival rates. ${ }^{[15-17]}$ The clinical outcome of the proton treatment for $\mathrm{HCC}$ reported in the literature is summarized in Table 1. Based on the conditions mentioned above, our estimation is that around $15-20 \%$ of Taiwanese HCC patients might benefit from proton beam treatment.

The treatment protocol for proton beam on HCC varied between centers, but hypofractionated schedule is a standard principle. ${ }^{[12-14]}$ The fraction number ranges from 5 fractions for small liver tumors as a stereotactic body radiation therapy (SBRT) to 35 fractions for tumors next to the bowel. ${ }^{[14]}$ In general, most centers administer 10-20 fractions, 3.8-6.6 GyE (Gray equivalent) per fraction, and from 63 to $76 \mathrm{GyE}$ for the total dose [Table 1].

Table 1: Summary of the literature reports for proton therapy in primary liver tumor

\begin{tabular}{|c|c|c|c|c|c|}
\hline Study & $n$ (period) & Site & Outcome & Toxicity $(n)$ & Evidence level* \\
\hline $\begin{array}{l}\text { Lee } \text { et al. (2014), KLCSG and } \\
\text { NCC, retrospective study }{ }^{[16]}\end{array}$ & $27(2008-2011)$ & $\begin{array}{l}\text { HCC } \\
\text { with } \\
\text { PVT }\end{array}$ & $\begin{array}{l}\text { 2-year OS: } 33 \% \text {; } \\
\text { 2-year LPFS: } 62 \% \text {; } \\
\text { PVT response rate: } 56 \%\end{array}$ & $\begin{array}{l}\text { Acute: G2 ALT elevation (3) } \\
\text { Late: G2 gastrointestinal toxicity (2) }\end{array}$ & $3 \mathrm{AD}$ \\
\hline $\begin{array}{l}\text { Sugahara et al. (2009), } \\
\text { University of Tsukuba, } \\
\text { retrospective study }{ }^{[17]}\end{array}$ & 35 (1991-2005) & $\begin{array}{l}\text { HCC } \\
\text { with } \\
\text { PVT }\end{array}$ & $\begin{array}{l}\text { 2-year OS: } 48 \% \text {; } \\
\text { 2-year LC: } 91 \% \text {; } \\
\text { PVT response rate: } 89 \%\end{array}$ & $\begin{array}{l}\text { Acute: G3 hematologic toxicity (2), G4 } \\
\text { hematologic toxicity (1) } \\
\text { Late: G3 duodenal ulcer (1) }\end{array}$ & $3 \mathrm{AD}$ \\
\hline $\begin{array}{l}\text { Mizumoto et al. }(2011) \\
\text { University of Tsukuba, } \\
\text { retrospective study }{ }^{[14]}\end{array}$ & $266(2001-2007)$ & $\mathrm{HCC}$ & $\begin{array}{l}\text { 5-year OS: } 48 \% \\
\text { 5-year PFS: } 12 \% \\
\text { 5-year LC: } 81 \%\end{array}$ & $\begin{array}{l}\text { Acute: } \mathrm{G} 3 \text { dermatitis (2) } \\
\text { Late: rib fracture (3), G3 dermatitis (1), } \\
\text { G3 gastrointestinal toxicity (3) }\end{array}$ & $3 \mathrm{AD}$ \\
\hline $\begin{array}{l}\text { Komatsu et al. }(2011) \text {, } \\
\text { HIBMC, retrospective study }{ }^{[13]}\end{array}$ & $242(2001-2009)$ & $\mathrm{HCC}$ & $\begin{array}{l}\text { 5-year OS: } 38 \% \\
\text { 5-year LC: } 90 \%\end{array}$ & $\begin{array}{l}\text { Late: G3 dermatitis (4), G3 biloma (1), } \\
\text { G3 gastrointestinal toxicity (2) }\end{array}$ & $3 \mathrm{AD}$ \\
\hline $\begin{array}{l}\text { Bush et al. }(2011), \text { LLUMC, } \\
\text { phase II study }{ }^{[18]}\end{array}$ & $76(1998-2006)$ & $\mathrm{HCC}$ & $\begin{array}{l}\text { 3-year PFS: } 60 \% \\
\text { (within Milan criteria), } 20 \% \\
\text { (outside Milan criteria); } \\
\text { 5-year LC: } 80 \%\end{array}$ & Late: G2 gastrointestinal toxicity (2) & $2 \mathrm{AD}$ \\
\hline $\begin{array}{l}\text { Kawashima et al. }(2005) \text {, } \\
\text { NCCHE (Japan), phase II } \\
\text { study }^{[1]}\end{array}$ & 30 (1999-2003) & $\mathrm{HCC}$ & $\begin{array}{l}\text { 2-year OS: } 66 \% \\
\text { 2-year LC: } 96 \%\end{array}$ & $\begin{array}{l}\text { Acute: } \mathrm{G} 3 \text { hematologic toxicity (10), G3 } \\
\text { transaminase elevation (5), G3 bilirubin } \\
\text { elevation (1) } \\
\text { Late: G3 skin toxicity (1) }\end{array}$ & $2 \mathrm{AD}$ \\
\hline $\begin{array}{l}\text { Chiba et al. (2005), University } \\
\text { of Tsukuba, retrospective } \\
\text { study }{ }^{[12]}\end{array}$ & $162(1985-1998)$ & $\mathrm{HCC}$ & $\begin{array}{l}\text { 5-year OS: } 24 \% \text {; } \\
\text { 5-year LC: } 87 \%\end{array}$ & $\begin{array}{l}\text { Acute: bilirubin elevation (3), hematologic } \\
\text { toxicity (9), transaminase elevation (18) } \\
\text { Late: gastrointestinal tract bleeding (2), } \\
\text { infection biloma (2) }\end{array}$ & $3 \mathrm{AD}$ \\
\hline
\end{tabular}

*The classification system developed by the National Cancer Institute's PDQ Adult Treatment Editorial Board about the strength of study design: $1=$ Randomized controlled trials, $2=$ Nonrandomized controlled trials, $3=$ Case series, $4=$ Best case series; the progressive alphabetic scale is used to indicate the scientific strength of endpoints: $\mathrm{A}=$ Total mortality, $\mathrm{B}=$ Cause-specific survival, $\mathrm{C}=$ Carefully assessed quality of life, $\mathrm{D}=\mathrm{Indirect}$ surrogates including disease-free survival, progression-free survival, tumor response rate. Abbreviations: KLCSG and NCC: Korean Liver Cancer Study Group and National Cancer Center; HIBMC: Hyogo Ion Beam Medical Center; LLUMC: Loma Linda University Medical Center; NCCHE: National Cancer Center Hospital East (Japan); HCC: Hepatocellular carcinoma; PVT: Portal vein tumor thrombosis; OS: Overall survival; LPFS: Local progression-free survival; PFS: Progression-free survival; LC: Local control; ALT: Alanine aminotransferase 


\section{Head and neck cancers including nasopharyngeal carcinoma}

Due to the limitations in the field size and conformity to the tumor, the passive scattering technique needs complex combinations such as patching or matching between fields to treat primary tumors and lymphatics in head and neck tumors. Skull base, paranasal sinus, and parotid gland tumors were the most common head and neck tumors treated by proton beam with passive scattering technique. However, several recent publications not only showed the feasibility of using spot beam scanning technique in delivering IMPT in head and neck cancer ${ }^{[19-21]}$ but also showed that the preliminary results are very promising. ${ }^{[3,22]}$

The potential benefits of IMPT in head and neck cancer mainly are due to sparing of normal tissues from the radiation dose. For ipsilateral lesions such as tonsil or buccal cancers, IMPT has a significantly lower dose than intensity-modulated X-ray (IMRT) in contralateral submandibular and parotid gland, oral cavity, spinal cord, and brain stem. ${ }^{[20]}$ For oropharyngeal cancer and nasopharyngeal cancer, the treatment target does not include the brain, oral cavity, submandibular gland, or esophagus. Compared to IMRT, IMPT spares substantial dose to these regions ${ }^{[23]}$ and preliminary results were very encouraging for using this technique. ${ }^{[22]}$ The result of a recent study showed that the percentage of oropharyngeal cancer patients requiring nasogastric tube feeding during concurrent chemoradiotherapy (CCRT) was significantly reduced from $46 \%$ by IMRT to $19 \%$ by IMPT. ${ }^{[24]}$ The clinical outcome of head and neck cancer patients treated by proton therapy, mainly by passive scattering technique, is summarized in Table 2.

In 2011, out of 4648 newly diagnosed oral cavity (excluding salivary gland) cancer patients in Taiwan, around $40 \%$ received radiotherapy as part of their first-line treatment. ${ }^{[8]}$ There were 1281 and 1579 patients with oropharyngeal and nasopharyngeal cancer, respectively; around $90 \%$ of them received radiotherapy as the main treatment. Overall, more than 4000 head and neck cancer patients might benefit from proton treatment; cases with skull base, paranasal sinus, and parotid gland tumors were not counted.

\section{Potential clinical benefits of proton therapy on cancers with high prevalence in Taiwan and in western countries}

The leading five cancers in Taiwan in the year 2011 were colon-rectal $(N=14,087)$, liver $(N=11,292)$, lung $(N=11,059)$, breast $(N=10,056)$, and head and neck $\left(N=6890\right.$; excluding NPC) ${ }^{[8]}$ Other than liver, head, and neck cancers, the rest are also leading cancers in the western countries. Among them, lung and left breast cancers have a greater potential to benefit from proton treatment.

\section{Primary lung cancer}

Medically inoperable early-stage and stage III lung cancers are two conditions for proton therapy. The dose to the normal lung is significantly lower for proton beam than for X-ray. ${ }^{[25,26]}$ The 4-year local control rate and disease-specific survival rate were $96 \%$ and $88 \%$, respectively, for peripheral $\mathrm{T} 1$ tumors treated by $70 \mathrm{GyE}$ proton beam in 10 fractions ${ }^{[27]}$ Clinical radiation pneumonitis was not a significant complication under such high-dose treatment by proton beam. None of the patients required steroid therapy for radiation pneumonitis and pulmonary function was well-maintained 1 year after treatment. ${ }^{[27]}$ In studies with doses of 52.8-80 GyE in 4-26 fractions, the local control rate was $81 \%$ and $75 \%$ for $\mathrm{T} 1$ and $\mathrm{T} 2$ lung cancer, respectively; and there was no difference between proton and carbon beam in the outcome. ${ }^{[28,29]}$ Radiation dose was found to be the most significant factor for local control ${ }^{[30]}$ and higher radiation dose could be achieved by using proton beam.

Concurrent chemoradiation is the front line treatment for stage III lung cancer; however, higher radiation doses by $\mathrm{X}$-ray bring more complications but no survival benefit. ${ }^{[31]}$ By employing proton beam, the mean total lung V5, V10, and V20 were significantly reduced, even when the radiation dose was increased from 63 Gy by X-ray to $74 \mathrm{GyE}$ by proton. ${ }^{[25]}$ Several studies showed that proton is a safe tool for dose escalation in stage III lung cancer ${ }^{[25,32,33]}$ and the preliminary results are very encouraging.

\section{Left breast cancer}

It has been reported that the risk of ischemic heart disease was increased in women with left breast cancer and treated with radiotherapy ${ }^{[34-36]}$ The increase is proportional to the mean dose to the heart and continues for at least 20 years ${ }^{[34]}$ For women with left breast cancer and receiving post-mastectomy radiotherapy by X-ray, it will be a great challenge to reduce the dose to the heart if the internal mammary chain is included in the treatment field. The dosimetric comparisons between X-ray or X-ray/electron and proton beam showed that proton is cardiac- and pulmonary-sparing $;{ }^{[37]}$ a report of early clinical outcome in 12 patients showed that this application of proton therapy is feasible and well tolerated. ${ }^{[38]}$ Proton therapy was also employed for partial breast irradiation in a Phase II trial; ${ }^{[39]}$ however, its clinical benefits need further justification. Proton therapy could be also applied to patients with left breast cancer and treated with breast conserving surgery; however, a good fixation method is needed to maintain positional reproducibility of a large breast.

In Taiwan, the number of cases with invasive cancer of the breast was 10,103 in year $2011 ; 49 \%$ of the patients received radiotherapy as part of their first course treatment. 
Table 2: Summary of the literature reports for proton therapy in head and neck cancers including nasopharyngeal carcinoma

\begin{tabular}{|c|c|c|c|c|c|c|}
\hline Study & $n$ (duration) & Site & Chemotherapy $(n)$ & Outcome & Toxicity $(n)$ & Evidence level* \\
\hline $\begin{array}{l}\text { Frank et al. (2013), } \\
\text { MDACC, case- } \\
\text { control study }{ }^{[24]}\end{array}$ & $26(2011-2012)$ & $\begin{array}{l}\text { Oropharyngeal } \\
\text { carcinoma }\end{array}$ & $\mathrm{I}, \mathrm{C}$ & Gastrostomy rate: $19 \%$ & Not reported & $3 \mathrm{C}$ \\
\hline $\begin{array}{l}\text { Okano et al. (2012), } \\
\text { NCCHE (Japan), } \\
\text { retrospective study }{ }^{[40]}\end{array}$ & $13(2006-2012)$ & $\begin{array}{l}\text { Nasal cavity } \\
\text { and paranasal } \\
\text { sinus } \\
\text { malignancies }\end{array}$ & $\mathrm{I}+\mathrm{C}(13)$ & $\begin{array}{l}\text { 5-year OS: } 76 \% ; \\
\text { 5-year PFS: } 34 \% ; \\
\text { response rate: } 92 \%\end{array}$ & $\begin{array}{l}\text { Acute: G3 mucositis (2) } \\
\text { Late: No }\end{array}$ & $3 \mathrm{AD}$ \\
\hline $\begin{array}{l}\text { Fukumitsu } \\
\text { et al. }(2012), \\
\text { University } \\
\text { of Tsukuba, } \\
\text { retrospective study }{ }^{[41]}\end{array}$ & $17(2001-2007)$ & $\begin{array}{l}\text { Nasal cavity } \\
\text { and paranasal } \\
\text { sinus } \\
\text { carcinoma }\end{array}$ & A (2), C (1) & $\begin{array}{l}\text { 5-year OS: } 16 \% \text {; } \\
\text { 5-year LC: } 18 \%\end{array}$ & $\begin{array}{l}\text { Acute: G3 mucositis (1), } \\
\text { G3 dermatitis (1) } \\
\text { Late: G4 bone } \\
\text { fracture (1), G4 } \\
\text { blindness (1), G3 brain } \\
\text { necrosis (1) }\end{array}$ & $3 \mathrm{AD}$ \\
\hline $\begin{array}{l}\text { Zenda et al. (2011), } \\
\text { NCCHE (Japan), } \\
\text { retrospective study }{ }^{[42]}\end{array}$ & 39 (1999-2006) & $\begin{array}{l}\text { Nasal cavity } \\
\text { and paranasal } \\
\text { sinus } \\
\text { malignancies }\end{array}$ & $\begin{array}{l}\text { I (10), C (1); } \\
\text { none (18) }\end{array}$ & $\begin{array}{l}\text { 3-year OS: } 59 \% \text {; } \\
\text { 3-year PFS: } 49 \% \text {; } \\
\text { 1-year LC: } 77 \%\end{array}$ & $\begin{array}{l}\text { Acute: G2 dermatitis (13) } \\
\text { Late: G3 cataract (1), } \\
\text { G3 bone necrosis (1), } \\
\text { G3 neuropathy (1), G4 } \\
\text { neuropathy (1), G5 CSF } \\
\text { leakage (1) }\end{array}$ & $3 \mathrm{AD}$ \\
\hline $\begin{array}{l}\text { Zenda et al. (2011), } \\
\text { NCCHE (Japan), } \\
\text { retrospective study }{ }^{[43]}\end{array}$ & $14(2004-2008)$ & $\begin{array}{l}\text { Mucosal } \\
\text { melanoma }\end{array}$ & Not mentioned & $\begin{array}{l}\text { 3-year OS: 58\%; } \\
\text { 2-year PFS: } 44 \% \text {; } \\
\text { 1-year LC: } 86 \%\end{array}$ & $\begin{array}{l}\text { Acute: G3 mucositis (3) } \\
\text { Late: G3 neuropathy (2) }\end{array}$ & $3 \mathrm{AD}$ \\
\hline $\begin{array}{l}\text { Truong et al. (2009), } \\
\text { MGH, retrospective } \\
\text { study }^{[44]}\end{array}$ & $20(1991-2005)$ & $\begin{array}{l}\text { Sphenoid sinus } \\
\text { malignancy }\end{array}$ & $\begin{array}{l}\text { I (4), I+C (4), } \\
C+A(1), C(1), \\
A(1)\end{array}$ & $\begin{array}{l}\text { 2-year OS: } 53 \% \text {; } \\
\text { 2-year DFS: } 31 \% \text {; } \\
\text { 2-year LC: } 86 \%\end{array}$ & $\begin{array}{l}\text { Acute: G3 mucositis (6), } \\
\text { G3 dermatitis (2) } \\
\text { Late: G2-3 nasal } \\
\text { obstruction secondary to } \\
\text { fibrous adhesions ( } 3 \text { ), G4 } \\
\text { pituitary dysfunction (1), } \\
\text { G5 CSF leakage (1) }\end{array}$ & $3 \mathrm{AD}$ \\
\hline $\begin{array}{l}\text { Slater et al. (2005), } \\
\text { LLUMC, prospective } \\
\text { study }^{[45]}\end{array}$ & $29(1991-2002)$ & $\begin{array}{l}\text { Oropharyngeal } \\
\text { cancer }\end{array}$ & None (29) & $\begin{array}{l}\text { 5-year DFS: } 65 \% \text {; } \\
\text { 5-year LRC: } 84 \% \\
\text { (photon+proton } \\
\text { concomitant boost) }\end{array}$ & $\begin{array}{l}\text { Late: G3 vocal } \\
\text { cord paralysis and } \\
\text { epiglottitis (1), G3 } \\
\text { subcutaneous fibrosis (1), } \\
\text { G3 trismus (1) }\end{array}$ & $2 \mathrm{D}$ \\
\hline $\begin{array}{l}\text { Tokuuye } \\
\text { et al. }(2004), \\
\text { University } \\
\text { of Tsukuba, } \\
\text { retrospective study }{ }^{[46]}\end{array}$ & $33(1983-2000)$ & $\begin{array}{l}\text { Head and neck } \\
\text { malignancies }\end{array}$ & $\begin{array}{l}\text { Chemotherapy (13), } \\
\text { none (20) }\end{array}$ & $\begin{array}{l}\text { 5-year OS: } 44 \% \text {; } \\
\text { 5-year PFS: } 29 \% \text {; } \\
\text { 5-year LC: } 74 \% \\
\text { (proton alone: } 17, \\
\text { proton+photon: } 16 \text { ) }\end{array}$ & $\begin{array}{l}\text { Late: osteonecrosis (2), } \\
\text { mucosal ulceration (3), } \\
\text { skin ulceration (1), } \\
\text { esophageal stenosis (1) }\end{array}$ & $3 \mathrm{AD}$ \\
\hline $\begin{array}{l}\text { Lin et al. (1999), } \\
\text { LLUMC, } \\
\text { retrospective study }{ }^{[4]]}\end{array}$ & $16(1991-1997)$ & $\begin{array}{l}\text { Recurrent } \\
\text { or persistent } \\
\text { nasopharyngeal } \\
\text { carcinoma }\end{array}$ & $\begin{array}{l}\text { Chemotherapy (12), } \\
\text { none (4) }\end{array}$ & $\begin{array}{l}\text { 2-year OS: } 50 \% \text {; } \\
\text { 2-year DFS: } 50 \% \text {; } \\
\text { 2-year LC: } 50 \%\end{array}$ & $\begin{array}{l}\text { Late: osteonecrosis (1), } \\
\text { chronic ulceration (1), } \\
\text { trismus (1), chronic } \\
\text { otitis (2) }\end{array}$ & $3 \mathrm{AD}$ \\
\hline
\end{tabular}

*The classification system developed by the National Cancer Institute's PDQ Adult Treatment Editorial Board about the strength of study design: 1=Randomized controlled trials, $2=$ Nonrandomized controlled trials, $3=$ Case series, $4=$ Best case series; the progressive alphabetic scale is used to indicate the scientific strength of endpoints: $\mathrm{A}=$ Total mortality, $\mathrm{B}=$ Cause-specific survival, $\mathrm{C}=$ Carefully assessed quality of life, $\mathrm{D}=$ Indirect surrogates including disease-free survival, progression-free survival, tumor response rate. Abbreviations: MDACC: University of Texas MD Anderson Cancer Center; NCCHE: National Cancer Center Hospital East (Japan); MGH: Massachusetts General Hospital; LLUMC: Loma Linda University Medical Center; Chemotherapy I: Induction; C: Concurrent; A: Adjuvant; OS: Overall survival; PFS: Progression-free survival; LC: Local control; LRC: Local regional control; DFS: Disease-free survival

\section{Cost-effectiveness consideration for proton therapy}

Due to the higher capital investment needed for the construction of a proton facility and operating costs, an average course of proton therapy was estimated to be about 2-3 times the cost of IMRT. ${ }^{[48-52]}$ With the more popular use of proton treatment, the cost-effectiveness comparisons between proton and X-ray treatment attract a lot of attention, especially on some specific sites such as left side breast cancer, head and neck cancer, pediatric cancer, and prostate cancer. ${ }^{[53]}$

For left breast cancer and head and neck cancer, a series report by Lundkvist et al. showed incremental cost-effectiveness ratio (iCER, cost/life years gain) of 34290 
and 3811, respectively. ${ }^{[54,55]}$ The assumption of their model included reducing the risks of ischemic heart disease, other cardiovascular diseases, and pneumonitis by proton treatment. For head and neck cancers, survival improvement and reduction of dental care cost were taken into account. In line with the widely accepted superiority of proton radiation in the prevention of long-term toxicity in childhood cancer, the evidence from pediatric medulloblastoma showed not only justified cost-effectiveness with higher quality-adjusted life years (QALY), but also lower costs $(\$ 33,000) .^{[50,56]}$

There was a lot of debate for the cost-effectiveness analysis of prostate cancer, usually evaluated with cost-effectiveness ratio (CER) or cost-utility analysis (CUA, cost/QALY). Both Lundkvist et al. and Konski et al. used Markov model, but reached dissimilar conclusions. $^{[6,55]}$ The Swedish group reported an iCER of 26,776, but the US group found it the iCER to be between $\$ 63,578$ for a 70 -year-old man and $\$ 55,726$ for a 60 -year-old man. This difference may be attributed to the differences in the parameters set for analysis; these included: Younger age (65 vs. 70), different techniques of photon therapy (conventional conformal radiotherapy vs. IMRT), different incremental costs (7953 vs. \$32,765), and different outcome estimates (20\% reduction in overall cancer mortality with $20 \%$ reduction in the risk of adverse effect, and $7 \%$ improvement in quality of life vs. $10 \%$ increase in freedom from biological failure at 10 years without impact on quality of life). ${ }^{[49]}$ Although the US group estimated over $\$ 50,000$ per QALY for prostate cancer proton therapy, there was another voice about raising the cutoff point to $\$ 100,000$, and to even $\$ 150,000$, since the standard $\$ 50,000$ has been used over two decades. ${ }^{[57]}$ Most of the cost-effectiveness analyses were based on retrospective data; more prospective clinical trials are needed to validate the assumptions.

\section{The clinical trial for proton therapy in Taiwan}

As described above, primary liver tumor and head and neck cancer (including nasopharyngeal carcinoma and buccal cancer) are two diseases with high prevalence in Taiwan, but not in western countries; therefore, proton centers in Taiwan have a greater responsibility to conduct clinical trials in these cancers. For example, the comparisons between proton therapy and radiofrequency ablation in patients not candidates for surgical resection but with medium-sized tumor $(3-7 \mathrm{~cm})$ should form a trial that may have a great impact for the management of primary liver tumor. Another example is to compare the quality of life during and after treatment for NPC patients treated by IMPT or X-ray radiotherapy (IMRT). These two clinical trials will be conducted at our proton center, either by a single institution or with international cooperation.

\section{Conclusions}

In the United States, prostate cancer is the dominant type of cancer treated by proton therapy, but this might not be the case in Taiwan. Due to the unique pattern of cancer types in Taiwan, the proportion of patients (excluding prostate cancer) suitable for proton therapy is higher in Taiwan than in USA. More prospective studies should be conducted to demonstrate that the dosimetric benefit, in terms of sparing the normal tissues, could translate into clinical benefits to improve patients' lives and survival in some diseases.

\section{Acknowledgment}

The authors would like to thank Tiffany Yu-ting Hong for her English editing.

\section{Financial support and sponsorship}

Nil.

\section{Conflicts of interest}

There are no conflicts of interest.

\section{REFERENCES}

1. Wilson RR. Radiological use of fast protons. Radiology 1946;47:487-91.

2. Wang Z, Nabhan M, Schild SE, Stafford SL, Petersen IA, Foote RL, et al. Charged particle radiation therapy for uveal melanoma: A systematic review and meta-analysis. Int J Radiat Oncol Biol Phys 2013;86:18-26.

3. Holliday EB, Frank SJ. Proton radiation therapy for head and neck cancer: A review of the clinical experience to date. Int J Radiat Oncol Biol Phys 2014;89:292-302.

4. Allen AM, Pawlicki T, Dong L, Fourkal E, Buyyounouski M, Cengel K, et al. An evidence based review of proton beam therapy: The report of ASTRO's emerging technology committee. Radiother Oncol 2012;103:8-11.

5. Dionisi F, Widesott L, Lorentini S, Amichetti M. Is there a role for proton therapy in the treatment of hepatocellular carcinoma? A systematic review. Radiother Oncol 2014;111:1-10.

6. Konski A, Speier W, Hanlon A, Beck JR, Pollack A. Is proton beam therapy cost effective in the treatment of adenocarcinoma of the prostate? J Clin Oncol 2007;25:3603-8.

7. Zietman AL. The Titanic and the Iceberg: Prostate proton therapy and health care economics. J Clin Oncol 2007;25:3565-6.

8. Health Promotion Administration MOHaW. Cancer Registry Annual Report, 2011. Taiwan 2014.

9. Lin SM. Local ablation for hepatocellular carcinoma in Taiwan. Liver Cancer 2013;2:73-83.

10. Members NGVP. NCCN Guideline Version 2 2014, Hepatobillary cancers. 2014.

11. Kawashima M, Furuse J, Nishio T, Konishi M, Ishii H, 
Kinoshita T, et al. Phase II study of radiotherapy employing proton beam for hepatocellular carcinoma. J Clin Oncol 2005;23:1839-46.

12. Chiba T, Tokuuye K, Matsuzaki Y, Sugahara S, Chuganji Y, Kagei K, et al. Proton beam therapy for hepatocellular carcinoma: A retrospective review of 162 patients. Clin Cancer Res 2005;11:3799-805.

13. Komatsu S, Fukumoto T, Demizu Y, Miyawaki D, Terashima K, Sasaki R, et al. Clinical results and risk factors of proton and carbon ion therapy for hepatocellular carcinoma. Cancer 2011;117:4890-904.

14. Mizumoto M, Okumura T, Hashimoto T, Fukuda K, Oshiro Y, Fukumitsu N, et al. Proton beam therapy for hepatocellular carcinoma: A comparison of three treatment protocols. Int J Radiat Oncol Biol Phys 2011;81:1039-45.

15. Hata M, Tokuuye K, Sugahara S, Kagei K, Igaki H, Hashimoto T, et al. Proton beam therapy for hepatocellular carcinoma with portal vein tumor thrombus. Cancer 2005;104:794-801.

16. Lee SU, Park JW, Kim TH, Kim YJ, Woo SM, Koh YH, et al. Effectiveness and safety of proton beam therapy for advanced hepatocellular carcinoma with portal vein tumor thrombosis. Strahlenther Onkol 2014;190:806-14.

17. Sugahara S, Nakayama H, Fukuda K, Mizumoto M, Tokita M, Abei M, et al. Proton-beam therapy for hepatocellular carcinoma associated with portal vein tumor thrombosis. Strahlenther Onkol 2009; 185:782-8.

18. Bush DA, Kayali Z, Grove RSlater JD. The safety and efficacy of high-dose proton beam radiotherapy for hepatocellular carcinoma: A phase 2 prospective trial. Cancer 2011;117:3053-9.

19. Quan EM, Liu W, Wu R, Li Y, Frank SJ, Zhang X, et al. Preliminary evaluation of multifield and single-field optimization for the treatment planning of spot-scanning proton therapy of head and neck cancer. Med Phys 2013;40:081709.

20. Kandula S, Zhu X, Garden AS, Gillin M, Rosenthal DI, Ang KK, et al. Spot-scanning beam proton therapy vs intensity-modulated radiation therapy for ipsilateral head and neck malignancies: A treatment planning comparison. Med Dosim 2013;38:390-4.

21. Liu W, Frank SJ, Li X, Li Y, Park PC, Dong L, et al. Effectiveness of robust optimization in intensity-modulated proton therapy planning for head and neck cancers. Med Phys 2013;40:051711.

22. Frank SJ, Cox JD, Gillin M, Mohan R, Garden AS, Rosenthal DI, et al. Multifield optimization intensity modulated proton therapy for head and neck tumors: A translation to practice. Int J Radiat Oncol Biol Phys 2014;89:846-53.

23. Taheri-Kadkhoda Z, Bjork-Eriksson T, Nill S, Wilkens JJ, Oelfke U, Johansson KA, et al. Intensity-modulated radiotherapy of nasopharyngeal carcinoma: A comparative treatment planning study of photons and protons. Radiat Oncol 2008;3:4.

24. Frank SJ, Rosenthal DI, Ang K, Sturgis EM, Chambers MS, Gunn GB, et al. Gastrostomy tubes decrease by over $50 \%$ with Intensity Modulated Proton Therapy (IMPT) during the treatment of oropharyngeal cancer patients: A case control study. Int J Radiat Oncol Biol Phys 2013;87:S144.

25. Chang JY, Zhang X, Wang X, Kang Y, Riley B, Bilton S, et al. Significant reduction of normal tissue dose by proton radiotherapy compared with three-dimensional conformal or intensity-modulated radiation therapy in Stage I or Stage III non-small-cell lung cancer. Int J Radiat Oncol Biol Phys 2006;65:1087-96.

26. Register SP, Zhang X, Mohan R, Chang JY. Proton stereotactic body radiation therapy for clinically challenging cases of centrally and superiorly located stage I non-small-cell lung cancer. Int J Radiat Oncol Biol Phys 2011;80:1015-22.

27. Bush DA, Cheek G, Zaheer S, Wallen J, Mirshahidi H, Katerelos A, et al. High-dose hypofractionated proton beam radiation therapy is safe and effective for central and peripheral early-stage non-small cell lung cancer: Results of a 12-year experience at Loma Linda University Medical Center. Int J Radiat Oncol Biol Phys 2013;86:964-8.

28. Fujii O, Demizu Y, Hashimoto N, Araya M, Takagi M, Terashima K, et al. A retrospective comparison of proton therapy and carbon ion therapy for stage I non-small cell lung cancer. Radiother Oncol 2013;109:32-7.

29. Iwata H, Demizu Y, Fujii O, Terashima K, Mima M, Niwa Y, et al. Long-term outcome of proton therapy and carbon-ion therapy for large (T2a-T2bN0M0) non-small-cell lung cancer. J Thorac Oncol 2013;8:726-35.

30. Kanemoto A, Okumura T, Ishikawa H, Mizumoto M, Oshiro Y, Kurishima $\mathrm{K}$, et al. Outcomes and prognostic factors for recurrence after high-dose proton beam therapy for centrally and peripherally located stage I non--small-cell lung cancer. Clin Lung Cancer 2014;15:e7-12.

31. Bradley J, Paulus R, Komaki R, Masters GA, Forster K, Schild SE, et al. A randomized phase III comparison of standard-dose (60 Gy) versus high-dose (74 Gy) conformal chemoradiotherapy with or without cetuximab for stage III non-small cell lung cancer: Results on radiation dose in RTOG 0617. in ASCO Annual Meeting 2013. Chicago, IL.

32. Chang JY, Komaki R, Lu C, Wen HY, Allen PK, Tsao A, et al. Phase 2 study of high-dose proton therapy with concurrent chemotherapy for unresectable stage III nonsmall cell lung cancer. Cancer 2011;117:4707-13.

33. Oshiro Y, Okumura T, Kurishima K, Homma S, Mizumoto M, Ishikawa $\mathrm{H}$, et al. High-dose concurrent chemo-proton therapy for Stage III NSCLC: Preliminary results of a Phase II study. J Radiat Res 2014;55:959-65.

34. Darby SC, Ewertz M, Mcgale P, Bennet AM, Blom-Goldman U, Bronnum $\mathrm{D}$, et al. Risk of ischemic heart disease in women after radiotherapy for breast cancer. N Engl J Med 2013;368:987-98.

35. Giordano SH, Kuo YF, Freeman JL, Buchholz TA, Hortobagyi GN, Goodwin JS. Risk of cardiac death after adjuvant radiotherapy for breast cancer. J Natl Cancer Inst 2005;97:419-24.

36. Chargari $\mathrm{C}$. The issue of radiation-induced cardiovascular toxicity: Preclinical highlights and perspectives on preventive strategies. Biomed J 2013;36:150-1.

37. Macdonald SM, Jimenez R, Paetzold P, Adams J, Beatty J, Delaney TF, et al. Proton radiotherapy for chest wall and regional lymphatic radiation; dose comparisons and treatment delivery. Radiat Oncol 2013;8:71.

38. Macdonald SM, Patel SA, Hickey S, Specht M, Isakoff SJ, Gadd M, et al. Proton therapy for breast cancer after mastectomy: Early outcomes of a prospective clinical trial. Int J Radiat Oncol Biol Phys 2013;86:484-90. 
39. Chang JH, Lee NK, Kim JY, Kim YJ, Moon SH, Kim TH, et al. Phase II trial of proton beam accelerated partial breast irradiation in breast cancer. Radiother Oncol 2013;108:209-14.

40. Okano S, Tahara M, Zenda S, Fuse N, Yoshino T, Doi T, et al. Induction chemotherapy with docetaxel, cisplatin and S-1 followed by proton beam therapy concurrent with cisplatin in patients with $\mathrm{T} 4 \mathrm{~b}$ nasal and sinonasal malignancies. Jpn J Clin Oncol 2012;42:691-6.

41. Fukumitsu N, Okumura T, Mizumoto M, Oshiro Y, Hashimoto T, Kanemoto A, et al. Outcome of T4 (International Union Against Cancer Staging System, $7^{\text {th }}$ edition) or recurrent nasal cavity and paranasal sinus carcinoma treated with proton beam. Int J Radiat Oncol Biol Phys 2012;83:704-11.

42. Zenda S, Kohno R, Kawashima M, Arahira S, Nishio T, Tahara M, et al. Proton beam therapy for unresectable malignancies of the nasal cavity and paranasal sinuses. Int J Radiat Oncol Biol Phys 2011;81:1473-8.

43. Zenda S, Kawashima M, Nishio T, Kohno R, Nihei K, Onozawa M, et al. Proton beam therapy as a nonsurgical approach to mucosal melanoma of the head and neck: A pilot study. Int J Radiat Oncol Biol Phys 2011;81:135-9.

44. Truong MT, Kamat UR, Liebsch NJ, Curry WT, Lin DT, Barker $\mathrm{FG} 2^{\text {nd }}$, et al. Proton radiation therapy for primary sphenoid sinus malignancies: Treatment outcome and prognostic factors. Head Neck 2009;31:1297-308.

45. Slater JD, Yonemoto LT, Mantik DW, Bush DA, Preston W, Grove RI, et al. Proton radiation for treatment of cancer of the oropharynx: Early experience at Loma Linda University Medical Center using a concomitant boost technique. Int J Radiat Oncol Biol Phys 2005;62:494-500.

46. Tokuuye K, Akine Y, Kagei K, Hata M, Hashimoto T, Mizumoto T, et al. Proton therapy for head and neck malignancies at Tsukuba. Strahlenther Onkol 2004;180:96-101.

47. Lin R, Slater JD, Yonemoto LT, Grove RI, Teichman SL, Watt DK, et al. Nasopharyngeal carcinoma: Repeat treatment with conformal proton therapy--dose-volume histogram analysis. Radiology 1999;213:489-94.

48. Goitein M, Jermann M. The relative costs of proton and X-ray radiation therapy. Clin Oncol 2003;15:S37-50.

49. Lievens Y, Pijls-Johannesma M. Health economic controversy and cost-effectiveness of proton therapy. Semin Radiat Oncol 2013;23:134-41.

50. Mailhot Vega RB, Kim J, Bussiere M, Hattangadi J, Hollander A, Michalski J, et al. Cost effectiveness of proton therapy compared with photon therapy in the management of pediatric medulloblastoma. Cancer 2013;119:4299-307.

51. Peeters A, Grutters JP, Pijls-Johannesma M, Reimoser S, De Ruysscher D, Severens JL, et al. How costly is particle therapy? Cost analysis of external beam radiotherapy with carbon-ions, protons and photons. Radiother Oncol 2010;95:45-53.

52. Pijls-Johannesma M, Pommier P, Lievens Y. Cost-effectiveness of particle therapy: Current evidence and future needs. Radiother Oncol 2008;89:127-34.

53. Epstein $\mathrm{K}$. Is spending on proton beam therapy for cancer going too far, too fast? BMJ 2012;344:e2488.

54. Lundkvist J, Ekman M, Ericsson SR, Isacsson U, Jonsson B, Glimelius B. Economic evaluation of proton radiation therapy in the treatment of breast cancer. Radiother Oncol 2005;75:179-85.

55. Lundkvist J, Ekman M, Ericsson SR, Jonsson B, Glimelius B. Proton therapy of cancer: Potential clinical advantages and cost-effectiveness. Acta Oncol 2005;44:850-61.

56. Lundkvist J, Ekman M, Ericsson SR, Jonsson B, Glimelius B. Cost-effectiveness of proton radiation in the treatment of childhood medulloblastoma. Cancer 2005;103:793-801.

57. Neumann PJ, Cohen JT, Weinstein MC. Updating cost-effectiveness--the curious resilience of the $\$ 50,000$-per-QALY threshold. N Engl J Med 2014;371:796-7.

This is an open access article distributed under the terms of the Creative Commons Attribution-NonCommercial-ShareAlike 3.0 License, which allows others to remix tweak, and build upon the work non-commercially, as long as the author is credited and the new creations are licensed under the identical terms.

For reprints contact: reprints@medknow.com 